\title{
EFFECT OF INTERLEUKIN-6 POLYMORPHISM ON FUNCTION OF THE RENAL ALLOGRAFT FUNTION AND EFFICACY OF IMMUNOSUPPRESSIVE THERAPY
}

\author{
MACIEJ KOTOWSKI ${ }^{1,2} *$, ANNA BOGACZ ${ }^{3,4}$, JOANNA BARTKOWIAK-WIECZOREK ${ }^{5}$, JERZY \\ SIENKO $^{2}$, KAROL TEJCHMAN $^{2}$, KRZYSZTOF DZIEWANOWSKI $^{6}$, MAREK OSTROWSKI ${ }^{2}$, \\ BOGUSŁAW CZERNY ${ }^{3,8}$, EDMUND GRZEŚKOWIAK ${ }^{5}$, BOGUSŁAW MACHALIŃSKI $^{1}$ \\ ${ }^{I}$ Department of General Pathology, Pomeranian Medical University, Szczecin, Poland \\ ${ }^{2}$ Department of General Surgery and Transplantation, Pomeranian Medical University, Szczecin, Poland \\ ${ }^{3}$ Department of Stem Cells and Regenerative Medicine, Institute of Natural Fibres and Medicinal Plants, Poznan, Poland \\ ${ }^{4}$ Department of Histocompatibility with Laboratory of Genetic Diagnostics, Regional Blood Centre, Poznan, Poland \\ ${ }^{5}$ Laboratory of Experimental Pharmacogenetics, Department of Clinical Pharmacy and Biopharmacy, University of Medical \\ Sciences, Poznan, Poland \\ ${ }^{6}$ Nephrology-Transplant Centre, Department of the Regional Public Hospital in Szczecin, Szczecin, Poland \\ ${ }^{7}$ Department of General Pharmacology and Pharmacoeconomics, Pomeranian Medical University, Szczecin, Poland
}

*corresponding author: maciej.j.kotowski@gmail.com

\begin{abstract}
The administration of immunosuppressive drugs affects the improvement of organ transplants. However, they can have a double effect, because it is well established that immunosuppressive drugs may result in nephrotoxicity related to the development of chronic graft dysfunction and acute rejection. The aim of the study was to determine a correlation between the therapeutic effect of immunosuppressants and IL-6 $-174 \mathrm{G}>\mathrm{C}$ polymorphism in patients after renal transplantation. A total of 185 patients receiving cyclosporine $(\mathrm{CsA})$ were involved. The genotype frequencies were determined using the real-time polimerase chain reaction (PCR) method. The highest doses of cyclosporine were used for carriers of the GG genotype (GG: $196.00 \mathrm{mg}$ vs GC: $169.70 \mathrm{mg}$ and $\mathrm{CC}: 170.00 \mathrm{mg}, \mathrm{p}=0.77)$. No such correlations were found for the determined blood concentration of CsA, because carriers of the CC genotype had slightly lower mean drug concentration in the blood as compared to the individuals with the GG and GC genotypes (CC: $112.41 \pm 6.95 \mathrm{ng} / \mathrm{mL}$ vs GG: $119.08 \pm 51.31 \mathrm{ng} / \mathrm{mL}$ and GC: $135.24 \pm 28.68 \mathrm{ng} / \mathrm{mL}, \mathrm{p}=0.78$ ). In addition, a comparison of the IL-6 genetic variants and the biochemical parameters found no potential risk for transplant rejection. However, the results obtained for creatinine suggest that patients with the CC genotype and receiving CsA may be at high risk of kidney graft rejection. These results indicate that IL-6 polymorphism may influence the dosage of immunosuppressive drugs in patients after transplantation as far as the individualization of therapy is concerned.
\end{abstract}

\section{Rezumat}

Administrarea medicamentelor imunosupresoare afectează funcționalitatea transplanturilor de organe. Cu toate acestea, ele pot avea un efect dublu, deoarece este bine stabilit că medicamentele imunosupresoare pot avea ca rezultat nefrotoxicitatea legată de disfuncția cronică a grefei și a respingerii acute. Scopul studiului a fost de a stabili o corelație între efectul terapeutic al imunosupresoarelor și polimorfismul interleukinei (IL)-6 -174G> C la pacienți, după transplant renal. Au fost înrolați 185 de pacienți care au primit ciclosporină (CsA). Frecvențele genotipului au fost determinate utilizând metoda PCR (polimerase chain reaction) în timp real. Cele mai mari doze de ciclosporină au fost utilizate pentru purtătorii genotipului GG (GG: 196,00 mg față de GC: 169,70 mg și CC: 170,00 mg, p = 0,77). Nu au fost găsite corelații pentru concentrația determinată în sânge a CsA, deoarece purtătorii genotipului CC au avut o concentrație medie mică de medicament în sânge, comparativ cu indivizii cu genotipuri GG și GC (CC: 112,41 $\pm 6,95 \mathrm{ng} / \mathrm{ml}$ față de GG: 119,08 $\pm 51,31 \mathrm{ng} / \mathrm{ml}$ și GC: $135,24 \pm$ $28,68 \mathrm{ng} / \mathrm{ml}, \mathrm{p}=0,78$ ). În plus, o comparație a variantelor genetice IL-6 şi a parametrilor biochimici nu a evidenţiat nici un risc potențial pentru respingerea transplantului. Cu toate acestea, rezultatele obținute pentru creatinină sugerează că pacienții cu genotipul CC și care primesc CsA pot prezenta un risc crescut de respingere a grefei renale. Aceste date indică faptul că polimorfismul IL-6 poate influența doza de medicamente imunosupresoare la pacienți după transplant.

Keywords: immunosuppression, renal transplantation, therapy individualization

\section{Introduction}

Kidney transplantation is the target treatment in the event of irreversible renal failure. The application of immunosuppressive drugs, such as cyclosporine (CsA), affects the improvement of the organ transplants, but it can lead to adverse reactions, especially to nephro-toxicity associated with the 
FARMACIA, 2018, Vol. 66, 5

development of chronic transplant dysfunction, risk of transplant loss, acute rejection, and increased mortality among patients. Therefore, the search for the optimal dosage regimen of immunosuppressive drugs in patients after renal transplantation continues.

The mechanism of action involves the inhibition of calcineurin activation. Calcineurin, which is responsible for the transcription of interleukin-2, plays an important role in the proliferation and activation of $\mathrm{T}$ lymphocytes [1]. The main effects of immunosuppressive drugs include inhibition of the activity of cytotoxic and helper lymphocytes, as well as promotion of the suppressor cells. Hence, many genetic factors unrelated to drug metabolism, such as inflammatory and anti-inflammatory factors (TNF- $\alpha$, TGF- $\beta$, interleukins $1,2,4,6,8,10,12$, interferon- $\gamma$, TLR4), may affect graft survival [2-5].

Studies have shown that increased production of TNF- $\alpha$ in the recipient may predispose them to acute or chronic rejection, while overexpression of the IL-6 gene provides protection against chronic rejection. In the case of reduced IL- 6 gene expression, an increase of TNF- $\alpha$ level is observed, which in turn elevates the risk of rejection of the transplanted organ [5-7].

IL-6 is a protein encoded by a gene located on chromosome 7p15-p21 and consists of 212 amino acids, including a signal sequence. Its molecular weight of 21 to $28 \mathrm{kDa}$ depends on the posttranslational modifications. IL-6 is produced by a number of immune system cells, such as monocytes, macrophages, T cells, activated B lymphocytes, neutrophils, natural killer cells, fibroblasts, endothelial cells, keratinocytes, and muscle cells [8]. It participates in megakaryopoiesis as well agranulopoiesis, and inhibits the production of pro-inflammatory cytokines TNF- $\alpha$ and IL-1 [9].

It has been shown that the $-174 \mathrm{G}>\mathrm{C}$ polymorphism of the IL-6 gene affects cytokine production. In homozygous CC patients, IL-6 production is decreased while GG homozygotes and GC heterozygotes show a normal level of this interleukin $[10,11]$. Therefore, it is considered that polymorphisms of genes encoding interleukin-6 (IL$6-174 \mathrm{G}>\mathrm{C}$ ) and tumour necrosis factor alpha (TNF$\alpha-308 \mathrm{G}>\mathrm{A}$ ) affect the physiological production of cytokines and may contribute to the occurrence of kidney graft rejection $[4,5]$.

The aim of the study was to evaluate the influence of IL-6 -174G $>$ C polymorphism on the immunosuppressant dose (cyclosporine) in patients after kidney transplantation. Patients who receive standard doses of these drugs are often exposed to toxic drug levels in the blood or are at risk of graft rejection due to insufficient immuno-suppression.

\section{Materials and Methods}

\section{Patients}

The study group included 185 patients after kidney transplantation who received immunosuppressive therapy. The patients were recruited at the Division of Nephrology and Kidney Transplantation, Regional Public Hospital in Szczecin, Poland, and the Department of General Surgery and Transplantation, Pomeranian Medical University in Szczecin, Poland in the years 2013 to 2015 . The study was accepted by the Bioethics Committee at Poznan University of Medical Sciences and Pomeranian Medical University in Szczecin, Poland. Patients were admitted consecutively. All patients were informed about the aim of the study and gave their written consent.

Clinical and biochemical parameters were analysed in order to determine the potential risk of graft rejection.

Genomic DNA isolation from venous blood samples was performed according to the manufacturer's protocol (QIAamp DNA Blood Mini Kit Qiagen, Germany). DNA purity and concentration were measured by spectrophotometry (EPOCH Spectrophotometer, Biokom). The analysis of $-174 \mathrm{G}>\mathrm{C}$ polymorphism in the IL-6 gene was determined by the real-time PCR method using LightCycler ${ }^{\circledR} 480$ (Roche Diagnostics). Fluorescent dye-labelled hybridization probes were used for genotyping. The analysis of the results was based on the melting curve, using LightCycler ${ }^{\circledR} 480$ Basic Software. A set of LightSNiPrs1800795 for IL6 polymorphism contains the appropriate concentrations of specific primers and probes for the amplified fragment, and was prepared according to the manufacturer's instructions.

In addition, a fasting whole blood concentration of the immunosuppressive drug was determined before drug administration. The analysis was performed using the ARCHITECT i2000SR analyser (Abbott). The ARCHITECT System Cyclosporine (Abbott) was used to determine the drug concentrations based on a chemiluminescent microparticle immunoassay (CMIA). Prior to the initiation of the automated analysis, a manual pretreatment step, in which the whole blood sample was extracted with a precipitation reagent and centrifuged, was performed. The supernatant was decanted into a Transplant Pre-treatment Tube, which was placed onto the analyser. The functional sensitivity of the ARCHITECT Cyclosporine assay was designed as $\leq 30.0 \mathrm{ng} / \mathrm{mL}$.

Statistical analysis

Statistical analysis was performed using SPSS version 17.0. Allele and genotype frequencies were assessed using the Pearson $\chi 2$ test. We also used the Pearson $\chi^{2}$ test to assess the Hardy-Weinberg equilibrium. 
FARMACIA, 2018, Vol. 66, 5

The analysis of the clinical and biochemical parameters and their relationship with IL-6 polymorphism was conducted using one-way ANOVA (SPSS Inc.). The p-value of $<0.05$ was considered as statistically significant.

\section{Results and Discussion}

Our study investigated the effect of $-174 \mathrm{G}>\mathrm{C}$ polymorphism of the IL- 6 gene on the concentration of
CsA in venous blood and the function of renal allograft. Genotype frequencies of $-174 \mathrm{G}>\mathrm{C}$ (rs1800795) poly-morphism in patients receiving cyclosporine are presented in Figure 1. The frequency distribution of the geno-types was consistent with the Hardy-Weinberg equilibrium. The analysis of selected clinical parameters between the carriers of different $-174 \mathrm{G}>\mathrm{C}$ poly-morphism is presented in Table I.

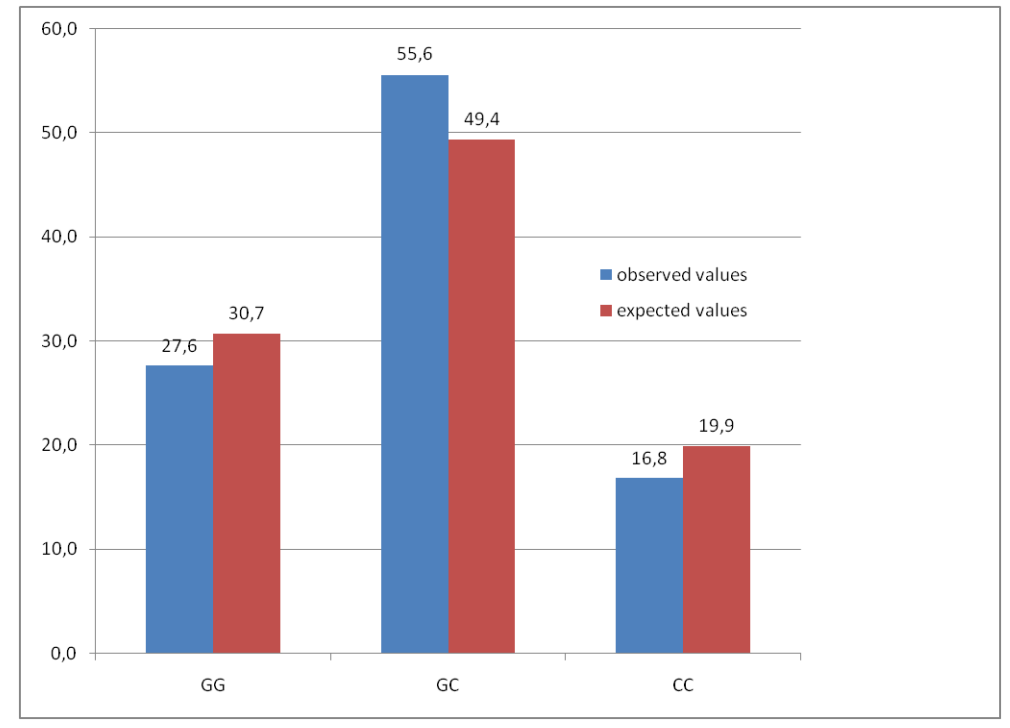

Figure 1.

Genotype frequencies of the $-174 \mathrm{G}>\mathrm{C}(\mathrm{rs} 1800795)$ polymorphism of the IL-6 gene in patients after transplantation receiving cyclosporine (CsA)

Table I

Comparison of selected clinical parameters between genotypes of $-174 \mathrm{G}>\mathrm{C}$ polymorphism of IL-6 gene in patients

\begin{tabular}{|c|c|c|c|c|c|c|c|c|}
\hline \multirow{2}{*}{ Parameter } & \multirow[b]{2}{*}{ Genotype } & \multirow[b]{2}{*}{ Number of patients } & \multirow[b]{2}{*}{ Mean \pm SD } & \multirow[b]{2}{*}{ SEM } & \multicolumn{4}{|c|}{ receiving cyclosporine (CsA) } \\
\hline & & & & & $95 \%$ CI & Min & Max & $P$ \\
\hline \multirow{4}{*}{$\begin{array}{l}\text { Weigh } \\
(\mathrm{kg})\end{array}$} & $\mathrm{GG}$ & 51 & $77.97 \pm 15.62$ & 2.19 & $73.58-82.37$ & 50.00 & 121.00 & \multirow{4}{*}{0.482} \\
\hline & $\mathrm{GC}$ & 102 & $78.14 \pm 16.20$ & 1.60 & $74.96-81.32$ & 46.00 & 120.00 & \\
\hline & $\mathrm{CC}$ & 31 & $82.16 \pm 21.87$ & 3.93 & $74.14-90.18$ & 40.00 & 139.00 & \\
\hline & Total & 184 & $78.77 \pm 17.10$ & 1.26 & $76.29-81.26$ & 40.00 & 139.00 & \\
\hline \multirow{4}{*}{$\begin{array}{l}\text { Height } \\
(\mathrm{cm})\end{array}$} & GG & 51 & $172.18 \pm 8.88$ & 1.24 & $169.68-174.67$ & 154.00 & 191.00 & \multirow[t]{4}{*}{0.053} \\
\hline & $\mathrm{GC}$ & 103 & $168.17 \pm 9.24$ & 0.91 & $166.37-169.98$ & 150.00 & 193.00 & \\
\hline & $\mathrm{CC}$ & 31 & $171.00 \pm 10.20$ & 1.83 & $167.26-174.74$ & 152.00 & 188.00 & \\
\hline & Total & 185 & $169.75 \pm 9.44$ & 0.69 & $168.38-171.12$ & 150.00 & 193.00 & \\
\hline \multirow{4}{*}{$\begin{array}{l}\mathrm{BMI} \\
\left(\mathrm{kg} / \mathrm{m}^{2}\right)\end{array}$} & GG & 51 & $26.29 \pm 5.02$ & 0.70 & $24.87-27.70$ & 20.08 & 41.64 & \multirow[t]{4}{*}{0.398} \\
\hline & GC & 103 & $27.31 \pm 5.60$ & 0.55 & $26.22-28.41$ & 17.81 & 40.75 & \\
\hline & $\mathrm{CC}$ & 31 & $27.85 \pm 5.85$ & 1.05 & $25.71-30.00$ & 17.31 & 42.90 & \\
\hline & Total & 185 & $27.12 \pm 5.49$ & 0.40 & $26.32-27.92$ & 17.31 & 42.90 & \\
\hline \multirow{4}{*}{$\begin{array}{l}\text { Systolic blood pressure } \\
(\mathrm{mmHg})\end{array}$} & GG & 51 & $131.86 \pm 12.73$ & 1.78 & $128.28-135.44$ & 110.00 & 160.00 & \multirow[t]{4}{*}{0.639} \\
\hline & GC & 103 & $133.54 \pm 13.35$ & 1.32 & $130.93-136.15$ & 100.00 & 180.00 & \\
\hline & $\mathrm{CC}$ & 31 & $131.45 \pm 13.67$ & 2.46 & $126.44-136.47$ & 110.00 & 170.00 & \\
\hline & Total & 185 & $132.73 \pm 13.20$ & 0.97 & $130.82-134.64$ & 100.00 & 180.00 & \\
\hline \multirow{4}{*}{$\begin{array}{l}\text { Diastolic blood pressure } \\
(\mathrm{mmHg})\end{array}$} & GG & 51 & $81.57 \pm 8.86$ & 1.24 & $79.08-84.06$ & 60.00 & 110.00 & \multirow[t]{4}{*}{0.324} \\
\hline & $\mathrm{GC}$ & 103 & $83.01 \pm 7.52$ & 0.74 & $81.54-84.48$ & 65.00 & 100.00 & \\
\hline & $\mathrm{CC}$ & 31 & $84.35 \pm 9.81$ & 1.76 & $80.76-87.95$ & 60.00 & 100.00 & \\
\hline & Total & 185 & $82.84 \pm 8.32$ & 0.61 & $81.63-84.04$ & 60.00 & 110.00 & \\
\hline
\end{tabular}

The analysis of the CsA dosage based on the genotypes of $-174 \mathrm{G}>\mathrm{C}$ polymorphism of the IL- 6 gene showed that patients with the GG genotype received the highest mean dose of cyclosporine (GG: 196.00 
FARMACIA, 2018, Vol. 66, 5

$\pm 54.81 \mathrm{mg}$ vs GC: $169.70 \pm 65.78 \mathrm{mg}$ and CC: $170.00 \pm 39.61 \mathrm{mg}, \mathrm{p}=0.77)$. Also, the maximum doses of the drug were observed for patients with the GC genotype (GC: $500.00 \mathrm{mg}$ vs GG: 400.00 $\mathrm{mg}$ and $\mathrm{CC}$ : $250.00 \mathrm{mg})$. However, no such correlations were found for the determined blood concentration of CsA, because carriers of the $\mathrm{CC}$ genotype had slightly lower mean drug concentration in the blood as compared to the individuals with the GG and GC genotypes (CC: $112.41 \pm 36.95 \mathrm{ng} / \mathrm{mL}$ vs GG: $119.08 \pm 51.31 \mathrm{ng} / \mathrm{mL}$ and GC: $135.24 \pm$ $28.68 \mathrm{ng} / \mathrm{mL}, \mathrm{p}=0.78)$ (Table II).

Table II

Comparison of selected biochemical parameters between genotypes of $-174 \mathrm{G}>\mathrm{C}$ polymorphism of IL- 6 gene in patients receiving cyclosporine (CsA)

\begin{tabular}{|c|c|c|c|c|c|c|c|c|}
\hline Parameter & Genotype & Number of patients & Mean \pm SD & SEM & $95 \%$ CI & Min & Max & $\mathbf{p}$ \\
\hline \multirow{4}{*}{$\begin{array}{l}\text { ALT } \\
(\mathrm{U} / 1)\end{array}$} & $\mathrm{GG}$ & 51 & $18.29 \pm 9.66$ & 1.35 & $15.58-21.01$ & 6.00 & 46.00 & \multirow[t]{4}{*}{0.717} \\
\hline & GC & 103 & $19.74 \pm 12.10$ & 1.19 & $17.37-22.10$ & 3.00 & 73.00 & \\
\hline & $\mathrm{CC}$ & 31 & $18.65 \pm 9.07$ & 1.63 & $15.32-21.97$ & 7.00 & 41.00 & \\
\hline & Total & 185 & $19.16 \pm 10.97$ & 0.81 & $17.57-20.75$ & 3.00 & 73.00 & \\
\hline \multirow{4}{*}{$\begin{array}{l}\text { AST } \\
(\mathrm{U} / 1)\end{array}$} & GG & 51 & $21.18 \pm 10.09$ & 1.41 & $18.34-24.02$ & 12.00 & 67.00 & \multirow[t]{4}{*}{0.589} \\
\hline & GC & 103 & $20.80 \pm 8.66$ & 0.85 & $19.10-22.49$ & 10.00 & 70.00 & \\
\hline & $\mathrm{CC}$ & 31 & $19.19 \pm 6.64$ & 1.19 & $16.76-21.63$ & 11.00 & 39.00 & \\
\hline & Total & 185 & $20.63 \pm 8.77$ & 0.64 & $19.36-21.90$ & 10.00 & 70.00 & \\
\hline \multirow{4}{*}{$\begin{array}{l}\text { Total cholesterol } \\
(\mathrm{mg} / \mathrm{dL})\end{array}$} & GG & 49 & $187.06 \pm 46.32$ & 6.62 & $173.76-200.36$ & 80.00 & 338.00 & \multirow[t]{4}{*}{0.542} \\
\hline & GC & 99 & $190.54 \pm 37.44$ & 3.76 & $183.07-198.00$ & 117.00 & 344.00 & \\
\hline & $\mathrm{CC}$ & 30 & $181.57 \pm 33.95$ & 6.20 & $168.89-194.24$ & 124.00 & 246.00 & \\
\hline & Total & 178 & $188.07 \pm 39.47$ & 2.96 & $182.23-193.91$ & 80.00 & 344.00 & \\
\hline \multirow{4}{*}{$\begin{array}{l}\text { Cholesterol-HDL } \\
(\mathrm{mg} / \mathrm{dL})\end{array}$} & GG & 39 & $64.13 \pm 19.97$ & 3.20 & $57.66-70.60$ & 27.60 & 118.80 & \multirow[t]{4}{*}{0.533} \\
\hline & GC & 64 & $63.70 \pm 20.19$ & 2.52 & $58.65-68.74$ & 31.50 & 118.20 & \\
\hline & $\mathrm{CC}$ & 19 & $58.07 \pm 23.86$ & 5.47 & $46.57-69.57$ & 31.20 & 105.20 & \\
\hline & Total & 122 & $62.96 \pm 20.65$ & 1.87 & $59.26-66.66$ & 27.60 & 118.80 & \\
\hline \multirow{4}{*}{$\begin{array}{l}\text { Cholesterol-LDL } \\
(\mathrm{mg} / \mathrm{dL})\end{array}$} & GG & 38 & $95.00 \pm 35.37$ & 5.73 & $83.37-106.63$ & 48.00 & 237.00 & \multirow[t]{4}{*}{0.962} \\
\hline & GC & 64 & $96.59 \pm 36.85$ & 4.61 & $87.39-105.80$ & 36.00 & 239.00 & \\
\hline & $\mathrm{CC}$ & 19 & $94.37 \pm 37.03$ & 8.50 & $76.52-112.22$ & 42.00 & 150.00 & \\
\hline & Total & 121 & $95.74 \pm 36.13$ & 3.28 & $89.24-102.25$ & 36.00 & 239.00 & \\
\hline \multirow{4}{*}{$\begin{array}{l}\text { Triglycerides } \\
(\mathrm{mg} / \mathrm{dL})\end{array}$} & GG & 39 & $142.87 \pm 71.11$ & 11.39 & $119.82-165.92$ & 48.00 & 404.00 & \multirow[t]{4}{*}{0.890} \\
\hline & $\mathrm{GC}$ & 64 & $140.55 \pm 64.49$ & 8.06 & $124.44-156.66$ & 52.00 & 334.00 & \\
\hline & $\mathrm{CC}$ & 19 & $148.89 \pm 62.69$ & 14.38 & $118.68-179.11$ & 58.00 & 268.00 & \\
\hline & Total & 122 & $142.59 \pm 65.93$ & 5.97 & $130.77-154.41$ & 48.00 & 404.00 & \\
\hline \multirow{4}{*}{$\begin{array}{l}\text { Total lipids } \\
(\mathrm{mg} / \mathrm{dL})\end{array}$} & GG & 39 & $640.77 \pm 148.00$ & 23.70 & $592.79-688.75$ & 430.00 & 1070.00 & \multirow{4}{*}{0.984} \\
\hline & GC & 64 & $639.42 \pm 133.41$ & 16.68 & $606.10-672.75$ & 450.00 & 1183.00 & \\
\hline & $\mathrm{CC}$ & 19 & $634.11 \pm 108.35$ & 24.86 & $581.88-686.33$ & 431.00 & 868.00 & \\
\hline & Total & 122 & $639.02 \pm 133.78$ & 12.11 & $615.05-663.00$ & 430.00 & 1183.00 & \\
\hline \multirow{4}{*}{$\begin{array}{l}\text { Creatinine } \\
(\mathrm{mg} / \mathrm{dL})\end{array}$} & GG & 51 & $1.63 \pm 0.64$ & 0.09 & $1.44-1.81$ & 0.67 & 3.81 & \multirow[t]{4}{*}{0.040} \\
\hline & GC & 103 & $1.53 \pm 0.59$ & 0.06 & $1.42-1.64$ & 0.73 & 4.12 & \\
\hline & $\mathrm{CC}$ & 31 & $1.85 \pm 0.68$ & 0.05 & $1.60-1.70$ & 1.06 & 4.31 & \\
\hline & Total & 185 & $1.61 \pm 0.63$ & 0.07 & $1.52-1.76$ & 0.67 & 4.31 & \\
\hline \multirow[t]{4}{*}{ eGFR } & GG & 51 & $32.08 \pm 9.91$ & 1.09 & $26.48-37.69$ & 15.93 & 57.68 & \multirow[t]{4}{*}{0.808} \\
\hline & GC & 103 & $29.99 \pm 7.38$ & 1.10 & $25.83-34.17$ & 18.62 & 59.63 & \\
\hline & $\mathrm{CC}$ & 31 & $29.64 \pm 8.26$ & 1.11 & $23.26-36.02$ & 14.96 & 53.14 & \\
\hline & Total & 185 & $30.51 \pm 8.55$ & 1.19 & $27.57-33.45$ & 14.96 & 59.63 & \\
\hline \multirow{4}{*}{$\begin{array}{l}\text { Uric acid } \\
(\mathrm{mg} / \mathrm{dL})\end{array}$} & GG & 49 & $7.29 \pm 1.19$ & 0.17 & $6.94-7.64$ & 4.40 & 9.60 & \multirow[t]{4}{*}{0.056} \\
\hline & GC & 102 & $6.74 \pm 1.47$ & 0.15 & $6.44-7.03$ & 3.70 & 10.30 & \\
\hline & $\mathrm{CC}$ & 31 & $7.24 \pm 1.85$ & 0.33 & $6.56-7.91$ & 4.10 & 10.90 & \\
\hline & Total & 182 & $6.97 \pm 1.49$ & 0.26 & $6.75-7.19$ & 3.70 & 10.90 & \\
\hline & GG & 51 & $119.08 \pm 51.31$ & 7.18 & $104.65-133.42$ & 89.00 & 256.00 & 0.778 \\
\hline the blood & $\mathrm{GC}$ & 103 & $135.24 \pm 28.68$ & 5.58 & $88.22-182.25$ & 95.60 & 315.90 & \\
\hline & $\mathrm{CC}$ & 31 & $112.41 \pm 36.95$ & 6.64 & $98.85-125.96$ & 47.70 & 172.00 & \\
\hline & Total & 185 & $126.96 \pm 61.73$ & 11.60 & $100.56-135.36$ & 47.70 & 315.90 & \\
\hline Dosage of CsA & GG & 50 & $196.00 \pm 54.81$ & 8.17 & $159.58-210.42$ & 100.00 & 400.00 & 0.772 \\
\hline$(\mathrm{mg})$ & GC & 100 & $169.70 \pm 65.78$ & 6.58 & $156.65-182.75$ & 100.00 & 500.00 & \\
\hline & $\mathrm{CC}$ & 30 & $170.00 \pm 39.61$ & 7.23 & $155.21-184.79$ & 100.00 & 250.00 & \\
\hline & Total & 180 & $172.06 \pm 61.73$ & 4.60 & $162.98-181.13$ & 100.0 & 500.00 & \\
\hline
\end{tabular}

ALT - alanine transaminase, AST - aspartate transaminase, eGFR - estimated glomerular filtration rate, *p $<0.05$ - comparison between genotypes and the analyzed parameters (one-way ANOVA test) 
The analysis of selected biochemical parameters between the genotypes of $-174 \mathrm{G}>\mathrm{C}$ polymorphism in patients treated with CsA showed a statistically significant difference only for creatinine (GG: $1.63 \pm$ $0.64 \mathrm{mg} / \mathrm{dL}, \mathrm{GC}: 1.53 \pm 0.59 \mathrm{mg} / \mathrm{dL}, \mathrm{CC}: 1.85 \pm 0.68$ $\mathrm{mg} / \mathrm{dL}, \mathrm{p}=0.04$ ) (Table II). The obtained results for creatinine suggest that patients with the $\mathrm{CC}$ genotype and receiving $\mathrm{Cs} A$ may be at high risk of kidney graft rejection, taking into account that IL-6 $174 \mathrm{G}>\mathrm{C}$ polymorphism affects cytokine production, causing its decrease in patients with the $\mathrm{CC}$ genotype. Besides, there were no episodes of acute rejection in the first 3 months after kidney

transplantation because the presented values of the biochemical parameters, such as creatinine, estimated glomerular filtration rate (eGFR), and potassium after transplantation suggested a successful transplant.

It needs to be highlighted that drug concentration to dose ratio ( $\mathrm{C} / \mathrm{D}$ ratio) is considered optimal for treatment evaluation and monitoring. Analysis of correlations between $\mathrm{C} / \mathrm{D}$ ratio and investigated $174 \mathrm{G}>\mathrm{C}$ poly-morphism of the IL- 6 gene showed that the highest value of $\mathrm{C} / \mathrm{D}$ ratio was observed for the GG genotype $(0.716 \pm 0.279)$ as compared to the CC genotype $(0.687 \pm 0.318)$ (Table III).

Table III

The concentration of the CsA in the blood to the dose of the drug (C/D ratio) depending on genotype for the IL-6 gene $174 \mathrm{G}>\mathrm{C}$ polymorphism

\begin{tabular}{lcccccc}
\hline & Mean \pm SD & SEM & 95\% CI & Min & Max & p \\
\hline $174 \mathrm{G}>\mathrm{C}$ & & & & & & \\
\hline GG & $0.716 \pm 0.279$ & 0.039 & $0.637-0.794$ & 0.20 & 1.60 & 0.322 \\
\hline GC & $0.706 \pm 0.288$ & 0.028 & $0.649-0.762$ & 0.02 & 1.75 \\
\hline CC & $0.687 \pm 0.318$ & 0.056 & $0.572-0.801$ & 0.01 & 1.57 \\
\hline Total & $0.706 \pm 0.289$ & 0.021 & $0.664-0.747$ & 0.01 & 1.75 \\
\hline
\end{tabular}

Immunosuppressants, such as cyclosporine, which are used to prevent allograft rejection after renal transplantation, have a narrow therapeutic index. Therefore, further studies are needed to individualize immunosuppressive therapy in order to prevent acute rejection. Insufficient levels of immunosuppressive drugs may cause rejection episodes, while excessively high drug levels increase the risk for infection and lead to other drug-specific adverse effects such as nephrotoxicity, hyperlipidaemia, hypertension, and post-transplant diabetes in certain patients. Determination of the optimal dosage of these drugs can significantly affect the fate of the transplanted organ [12-15]. Much attention has been paid to the studies on the impact of inflammatory processes on transplant rejection. The intensity of the immune response mainly depends on the cytokines which exhibit anti-inflammatory and proinflammatory effects. Differences in the expression may be due to the presence of polymorphic variants of genes encoding various cytokines, which can affect immunosuppressant dose determination [16].

In our study we evaluated the effect of $-174 \mathrm{G}>\mathrm{C}$ poly-morphism in the IL-6 gene on immunosuppressive drug-dose to patients after renal transplantation, and the potential risk for graft rejection based on the analysis of the clinical and biochemical parameters. This fact may be due to genotype-dependent IL-6 expression because most authors claim that the GC and GG genotypes determine the increased IL- 6 production, whereas the $\mathrm{CC}$ genotype is responsible for the low level of interleukin, which leads to increased production of TNF- $\alpha$ and, consequently, to increased risk of kidney graft rejection [5, 11, 17]. In the case of cyclosporine, we observed that patients with the GG genotype received the highest dose as compared to the GC and CC geno-types. Also, blood concentration of CsA remained at different levels with respect to the examined genotypes of IL-6. However, to the best of our knowledge, the literature offers no studies on the possible correlation between IL-6 polymorphism and immunosuppressant dose. Only an analysis of the genotype with the expression level of the IL- 6 gene was performed [5, 11]. Therefore, our study represents a new approach to the individualization of immunosuppressive therapy based on inflammatory markers.

Moreover, Fishman et al. have demonstrated that an increase of the IL-6 expression is associated with the $-174 \mathrm{GG}$ genotype [11]. Other studies have indicated that the $G$ allele of $-174 \mathrm{G}>\mathrm{C}$ polymorphism leads to normal transcriptional activity of the IL- 6 promoter, while the $\mathrm{C}$ allele reduces its activity [18]. In addition, it is concluded that the presence of homozygous $\mathrm{CC}$ genotype decreases the IL-6 level, while the GG and GC genotypes affect the normal production of this cytokine $[19,20]$. Furthermore, an analysis of the impact of $-174 \mathrm{G}>\mathrm{C}$ IL-6 polymorphism on the outcome of transplantation revealed a 3-fold increase of the risk of chronic kidney graft rejection (CR) in $-174 \mathrm{CC}$ homozygous recipients. It has been suggested that the $-174 \mathrm{G}$ allele reduces the risk of CR [21]. Another study has shown that the presence of the $-174 \mathrm{C}$ allele increases the risk of graft loss by over 3-fold, while an 8-fold higher risk of rejection in the first three years after transplantation 
FARMACIA, 2018, Vol. 66, 5

is observed in -174CC homozygotes [7]. The presence of the $-174 \mathrm{GG}$ genotype leading to high IL-6 expression affects long-term kidney function [22]. However, numerous other authors found no such correlations [23-25].

An analysis conducted among a Hindu population after kidney transplantation and in organ donors showed that serum TNF- $\alpha$ level was lower in patients with the GG genotype, while serum IL-6 level was higher in individuals with the GG genotype. In addition, rejection of the organ was observed in all patients who had higher TNF- $\alpha$ and IL-6 levels. Hence, it was claimed that high levels of TNF- $\alpha$ and IL-6 increase the risk of acute organ transplant rejection [26]. In addition, Pawlik et al showed that IL-6 -174 promoter poly-morphism may be a genetic factor influencing renal allograft survival, especially among renal transplant recipients with the GG genotype (high expression of IL-6) compared to the patients with the $\mathrm{C}$ allele [27].

So far, the examined IL-6 polymorphism has not been found to be correlated with the dose of immuno-suppressive drugs. Therefore, studies in this area will help to solve the problem of therapy personalization and simultaneously provide valuable information on the effects of IL-6 on the dosage regimen of immuno-suppressive drugs.

In addition, the risk of complications after organ transplantation, for example acute rejection (AR) or chronic rejection (CR), is connected not only with factors dependent on the recipient, but also the donor organ based on its genetic profile. It was shown that in the donor, the $-174 \mathrm{CC}$ genotype of IL-6 is associated with the development of CR and an increased risk of $\mathrm{AR}$ in the recipient, regardless of histocompatibility complex HLA-DR [28, 29]. In addition, the development of chronic interstitial fibrosis with atrophy of renal tubules was often associated with the $-174 \mathrm{CC}$ genotype of the IL-6 gene [30]. However, other researchers have not confirmed these findings [23].

It is well known that THE drug concentration of CsA in blood is strongly associated with CYP3A activity. However, the more we know about pharmacogenetic factors, the more effectively we can choose the therapy. Hopefully, in the near future we will be able to create the genetic ID for each patient. Similar conclusions are derived from previously published data [31].

\section{Conclusions}

These results confirm the important role of cytokines in renal transplantation and their impact on the outcome of transplantation. Hence, studies on gene polymorphisms of cytokines associated with the onset of organ rejection reactions would allow the selection of the most suitable donor, and the identification of the clinical and genetic factors which may affect the occurrence of rejection. Moreover, the results of future studies can facilitate the selection of the optimal treatment strategy with immunosuppressive drugs in individualized therapy. The abovedescribed tendencies could be the call for extensive studies including, e.g. drug pharmacokinetics. This is more important, considering that cyclosporine is not used only to treat patients after transplantation.

\section{Acknowledgement}

This article is dedicated to the memory of Professor Przemyslaw M. Mrozikiewicz. The study was supported by the National Science Centre, Grant no. UMO-2011/03/B/NZ7/06550.

\section{References}

1. Karemperis N, Povlsen J, Højskov C, Poulsen JH, Pedersen AR, Jørgensen KA, Comparison of the pharmacokinetics of tacrolimus and cyclosporine at equivalent molecular doses. Transplant Proc., 2003; 35: 1314-1318.

2. Massy ZA, Guijarro C, Wiederkehr MR, Ma JZ, Kasiske BL, Chronic renal allograft rejection: immunologic and nonimmunologic risk factors. Kidney Int., 1996; 49: 518-524.

3. Zaza G, Granata S, Sallustio F, Grandaliano G, Schena FP, Pharmacogenomics: a new paradigm to personalize treatments in nephrology patients. Clin Exp Immunol., 2010; 159: 268-280.

4. Alakulppi NS, Kyllönen LE, Jäntti VT, Matinlauri IH, Partanen J, Salmela KT, Laine JT, Cytokine gene polymorphisms and risks of acute rejection and delayed graft function after kidney transplantation. Transplantation, 2004; 78: 14221428.

5. Kocierz M, Kujawa-Szewieczek A, Kolonko A, Chudek J, Wiecek A, The influence of selected cytokine gene polymorphisms on the occurrence of acute and chronic rejection and on kidney graft survival. Postepy Hig Med Dośw. (online), 2009; 63: 613-626. (available in Polish)

6. Hahn AB, Kasten-Jolly JC, Constantino DM, Graffunder E, Singh TP, Shen GK, Conti DJ, TNFalpha, IL-6, IFN- $\gamma$ and IL-10 gene expression polymorphisms and the IL-4 receptor alpha-chain variant Q576R: effects on renal allograft outcome. Transplantation, 2001; 72: 660-665.

7. Müller-Steinhardt M, Härtel C, Müller B, Kirchner $\mathrm{H}$, Fricke L, The interleukin-6 -174 promoter polymorphism is associated with long-term kidney allograft survival. Kidney InKirchner H, Fricke L, $t$., 2002; 62: 1824-1827.

8. Ho LJ, Luo SF, Lai JH, The biological effects of interleukin-6: Clinical applications in autoimmune diseases and cancers. Biochem Pharmacol., 2015; 97: 16-26.

9. Schindler R, Mancilla J, Endres S, Ghorbani R, Clark SC, Dinarello CA, Correlations and interactions in the production of interleukin-6 (IL6), IL-1 and tumor necrosis factor (TNF) in human 
FARMACIA, 2018, Vol. 66, 5

blood mononuclear cells: IL-6 suppresses IL-1 and TNF. Blood, 1990; 75: 40-47.

10. Kalinka J, Bitner A, Selected cytokine gene polymorphisms and the risk of preterm delivery in the population of Polish women. Ginekol Pol., 2009; 80: 111-117. (available in Polish)

11. Fishamn D, Faulds G, Jeffery R, Mohamed-Ali V, Yudkin JS, Humphries S, Woo P, The effect of novel polymorphisms in the interleukin-6 (IL-6) gene on IL-6 transcription and plasma IL-6 levels, and an association with systemic-onset juvenile chronic arthritis. J Clin Invest., 1998; 102: 1369-1376.

12. Haubitz M, Acute and long-term toxicity of cyclophosphamide. Transplantationsmedizin, 2007; 19: 26-31.

13. Coscia LA, Constantinescu S, Davison JM, Moritz MJ, Armenti VT, Immunosuppressive drugs and fetal outcome. Best Pract Res Clin Obstet Gynaecol., 2014; 28: 1174-1187.

14. Cilião HL, Ribeiro DL, Camargo-Godoy RB, Specian AF, Serpeloni JM, Cólus IM, Cytotoxic and genotoxic effects of high concentrations of the immunosuppressive drugs cyclosporine and tacrolimus in MRC-5 cells. Exp Toxicol Pathol., 2015; 67: 179-187.

15. Trevillian $P$, Immunosuppressants - clinical applications. Aust Prescr., 2006; 29: 102-108.

16. Seyhun Y, Ciftci HS, Kekik C, Karadeniz MS, Tefik T, Nane I, Turkmen A, Oguz FS, Aydin F, Genetic association of interleukin-2, interleukin-4, interleukin-6, transforming growth factor- $\beta$, tumor necrosis factor- $\alpha$ and blood concentrations of calcineurin inhibitors in Turkish renal transplant patients. Int J Immunogenet., 2015; 42: 147-160.

17. Gaber W, Azkalany GS, Gheita TA, Mohey A, Sabry R, Clinical significance of serum interleukin6 and $-174 \mathrm{G} / \mathrm{C}$ promoter polymorphism in Rheumatoid arthritis patients. Egypt Rheumatol., 2013; 35: 107-113.

18. Velez DR, Fortunato SJ, Williams SM, Menon R, Interleukin-6 (IL-6) and receptor (IL6-R) gene haplotypes associate with amniotic fluid protein concentrations in preterm birth. Hum Mol Genet., 2008; 17: 1619-1630.

19. Simhan HN, Krohn MA, Roberts JM, Zeevi A, Caritis SN, Interleukin-6 promoter -174 polymorphism and spontaneous preterm birth. Am J Obstet Gynecol., 2003; 189: 915-918.

20. Härtel C, Finas D, Ahrens P, Kattner E, Schaible T, Müller D, Segerer H, Albrecht K, Möller J, Diedrich K, Göpel W, Genetic Factors in Neonatology Study Group, Polymorphisms of genes involved in innate immunity: association with preterm delivery. Mol Hum Reprod., 2004; 10: 911-915.

21. Pawlik A, Domański L, Różański J, Florczak M, Wrześniewska J, Dutkiewicz G, Dąbrowska-Żamojcin E, Gawrońska-Szklarz B, The cytokine gene polymorphisms in patients with chronic kidney graft rejection. Transpl Immunol., 2005; 14: 49-52.
22. Müller-Steinhardt M, Fricke L, Müller B, Ebel B, Kirchner H, Härtel C, Cooperative influence of the interleukin-6 promoter polymorphisms $-597,-572$ and -174 on long-term kidney allograft survival. Am J Transplant., 2004; 4: 402-406.

23. Breulmann B, Bantis C, Siekierka M, Blume C, Aker S, Kuhr N, Grabensee B, Ivens K, Influence of cytokine genes polymorphisms on long-term outcome in renal transplantation. Clin Transplant., 2007; 21: 615-624.

24. Gendzekhadze K, Rivas-Vetencourt P, Montano RF, Risk of adverse post-transplant events after kidney allograft transplantation as predicted by CTLA-4 +49 and TNF- $\alpha-308$ single nucleotide polymorphisms: a preliminary study. Transpl Immunol., 2006; 16: 194-199.

25. Loucaidou M, Stitchbury J, Lee J, Borrows R, Marshall SE, McLean AG, Cairns T, Griffith M, Hakim N, Palmer A, Papalois V, Welsh K, Taube $\mathrm{D}$, Cytokine polymorphisms do not influence acute rejection in renal transplantation under tacrolimus-based immunosuppression. Transplant Proc., 2005; 37: 1760-1761.

26. Chandel N, Minz M, Sakhuja V, Jha V, TNF- $\alpha$ and IL-6 gene polymorphism are associated with predisposition to ESRD and their post-transplant levels correlate with acute rejection. Transplantation, 2010; 90(Suppl. 2S): 921.

27. Pawlik A, Domański L, Różański J, Czerny B, Juzyszyn Z, Dutkiewicz G, Myślak M, Hałasa M, Słojewski M, Dąbrowska-Żamojcin E, The association between cytokine gene polymorphisms and kidney allograft survival. Ann Transplant., 2008; 13: 54-58.

28. Ligeiro D, Sancho MR, Papoila A, Barradinhas AM, Almeida A, Calão S, Machado D, Nolasco F, Guerra J, Sampaio MJ, Trindade H, Impact of donor and recipient cytokine genotypes on renal allograft outcome. Transplant Proc., 2004; 36: 827829.

29. Marshall SE, McLaren AJ, McKinney EF, Bird TG, Haldar NA, Bunce M, Morris PJ, Welsh K, Donor cytokine genotype influences the development of acute rejection after renal transplantation. Transplantation, 2001; 71: 469-476.

30. Nikolova PN, Ivanova MI, Mihailova SM, Myhailova AP, Baltadjieva DN, Simeonov PL, Paskalev EK, Naumova EJ, Cytokine gene polymorphism in kidney transplantation -impact of TGF- $\beta 1$, TNF- $\alpha$ and IL- 6 on graft outcome. Transpl Immunol., 2008; 18: 344-348.

31. Kotowski M, Bogacz A, Bartkowiak-Wieczorek J, Sieńko J, Procyk D, Dziewanowski K, Ostrowski M, Czerny B, Grześkowiak E, Machaliński B, The influence of the tumor necrosis factor-alpa$308 \mathrm{G}>\mathrm{A}$ polymorphism on the efficacy of immunosuppressive therapy in patients after kidney transplantation. J Physiol Pharmacol., 2016; 67: 819-826. 